\title{
Bioprospecting of Microbes for Valuable Compounds to Mankind
}

\author{
Nurul-Syakima Ab Mutalib ${ }^{1}$, Sunny Hei Wong ${ }^{2}$, Hooi-Leng Ser ${ }^{3}$, Acharaporn Duangjai ${ }^{4,5}$, Jodi Woan- \\ Fei Law ${ }^{3}$, Shanti Ratnakomala ${ }^{6}$, Loh Teng-Hern Tan ${ }^{3}$, Vengadesh Letchumanan ${ }^{3 *}$ \\ ${ }^{1}$ UKM Medical Molecular Biology Institute (UMBI), UKM Medical Centre, Universiti Kebangsaan Malaysia, Kuala \\ Lumpur, Malaysia \\ ${ }^{2} \mathrm{Li}$ Ka Shing Institute of Health Sciences, Department of Medicine and Therapeutics, The Chinese University of Hong Kong, \\ Shatin, Hong Kong \\ ${ }^{3}$ Novel Bacteria and Drug Discovery (NBDD) Research Group, Microbiome and Bioresource Research Strength (MBRS), \\ Jeffrey Cheah School of Medicine and Health Sciences, Monash University Malaysia, 47500 Bandar Sunway, Selangor \\ Darul Ehsan, Malaysia \\ ${ }^{4}$ Division of Physiology, School of Medical Sciences, University of Phayao, Phayao, Thailand \\ ${ }^{5}$ Center of Health Outcomes Research and Therapeutic Safety (Cohorts), School of Pharmaceutical Sciences, University of \\ Phayao, Phayao, Thailand \\ ${ }^{6}$ Research Center for Biotechnology, Indonesia Institute of Sciences (LIPI), Cibinong 16911, Indonesia
}

\begin{abstract}
The most biological multiplicity on this planet is almost certainly concealed in soils. Many valuable bacteria had been extensively dispersed in soils worldwide, with soils from terrestrial, desserts and Antarctic. Hence, soils become an intensively utilized ecological niche for the inhabitants to generate various useful biologically active natural products such as antibiotics, antifungal, antiviral, antioxidant, neuroprotection, anticancer and other important compounds. Bacteria including Actinobacteria have been exceptionally valuable for the pharmaceutical industry due to their limitless capability to generate secondary metabolites with various biological activities and chemical structure. Therefore, this article aims to provide critical insight of bioprospecting of microbes for valuable compounds to mankind.
\end{abstract}

Keywords: Bioprospecting; microbes; compounds; metabolites; actinobacteria; soil

Received: $29^{\text {th }}$ April 2020

Accepted: $29^{\text {th }}$ May 2020

Published Online: $7^{\text {th }}$ June 2020
*Correspondence: Vengadesh Letchumanan, Novel Bacteria and Drug Discovery (NBDD) Research Group, Microbiome and Bioresource Research Strength (MBRS), Jeffrey Cheah School of Medicine and Health Sciences, Monash University Malaysia, 47500 Bandar Sunway, Selangor Darul Ehsan, Malaysia; vengadesh. letchumanan1@monash.edu.

Citation: Ab Mutalib NS, Wong SH, Ser HL, et al. Bioprospecting of Microbes for Valuable Compounds to Mankind. Prog Microbes Mol Biol 2020; 3(1): a0000088. https://doi.org/10.3687/pmmb.a0000088.

\section{INTRODUCTION}

Biotechnology is an illustration of biodiversity as new products via the utilization of living organisms and bioprocesses in medicine, engineering, technology, and other fields that required bioproducts. The greater the biodiversity offered, the greater probabilities of discoveries that could be transformed into vital technologies ${ }^{[1]}$. The estimation of the environmental and economic gains that are a direct or indirect result of microbial diversity were approximate to be in the range of 16-54 trillion US dollars per year, with an average of 33 trillion US dollars per year $^{[2]}$.

The primary and secondary metabolism of prokaryotes has been utilized by industrial for the creation of diverse products such as antibiotics ${ }^{[3-6]}$, amino $\operatorname{acids}^{[7,8]}$, nucleotides ${ }^{[7]}$, organic acids ${ }^{[9]}$ and vitamins ${ }^{[10]}$. Bacteria like Actinobacteria are a particularly rich source of compounds with activities such as antimicrobial ${ }^{[6,11-22]}$, anticancer $^{[23-29]}$, antioxidants ${ }^{[30-35]}$, neuroprotective ${ }^{[36,37]}$, enzymes $^{[38-41]}$ and immunosuppressive ${ }^{[29]}$ as illustrated by Figure 1. Bérdy $(2005)^{[42]}$ reported that in 2002, over 10,000 bioactive compounds (45\% of all microbial metabolites) were obtained from filamentous Actinobacteria, out of which 7600 (75\%) were obtained from Streptomyces and 2500 (25\%) from rare Actinomycetes for instance Actinomadura, Streptoverticillium and Micromonospora.

Despite the tremendous success of the past in obtaining 
useful secondary metabolite, the probabilities of discovery novel biologically active molecules from bacteria such as Actinobacteria was reduced and appears to be reaching a saturation curve. Recently, isolating well known Actinobacteria such as Streptomyces from diverse environments were reported to obtain similar compound, potentially due to regular genetic exchange between species ${ }^{[43]}$. These challenges had led to intensely amplified in serious demand for new structures in pharmacology, hence propelled the investigation of new habitats with poorly explored areas and uncommon environments to become vital for the discovery of novel bacteria (e.g. Actinobacteria) and useful metabolites ${ }^{[44-55]}$. Reports from poorly explored areas from these regions (e.g. Antarctic, Australia, China, Malaysia and Jordan) suggested that the investigation of new habitats remain to be valuable in discovering novel microorganisms and useful metabolites ${ }^{[47,56-61]}$. Moreover, the progression of new selective methods allows the screening and isolation of 'rare' Actinobacteria that can lead to finding useful bioactive compounds ${ }^{[62-64]}$. The finding of "rare" Actinobacteria has increased the array and diversity of genetic resources available for biotechnological utilization ${ }^{[62-66]}$. It is apparent that the findings of novel bacteria such as Actinobacteria could increase the discovery novel bioactive metabolites ${ }^{[62,66-68]}$.

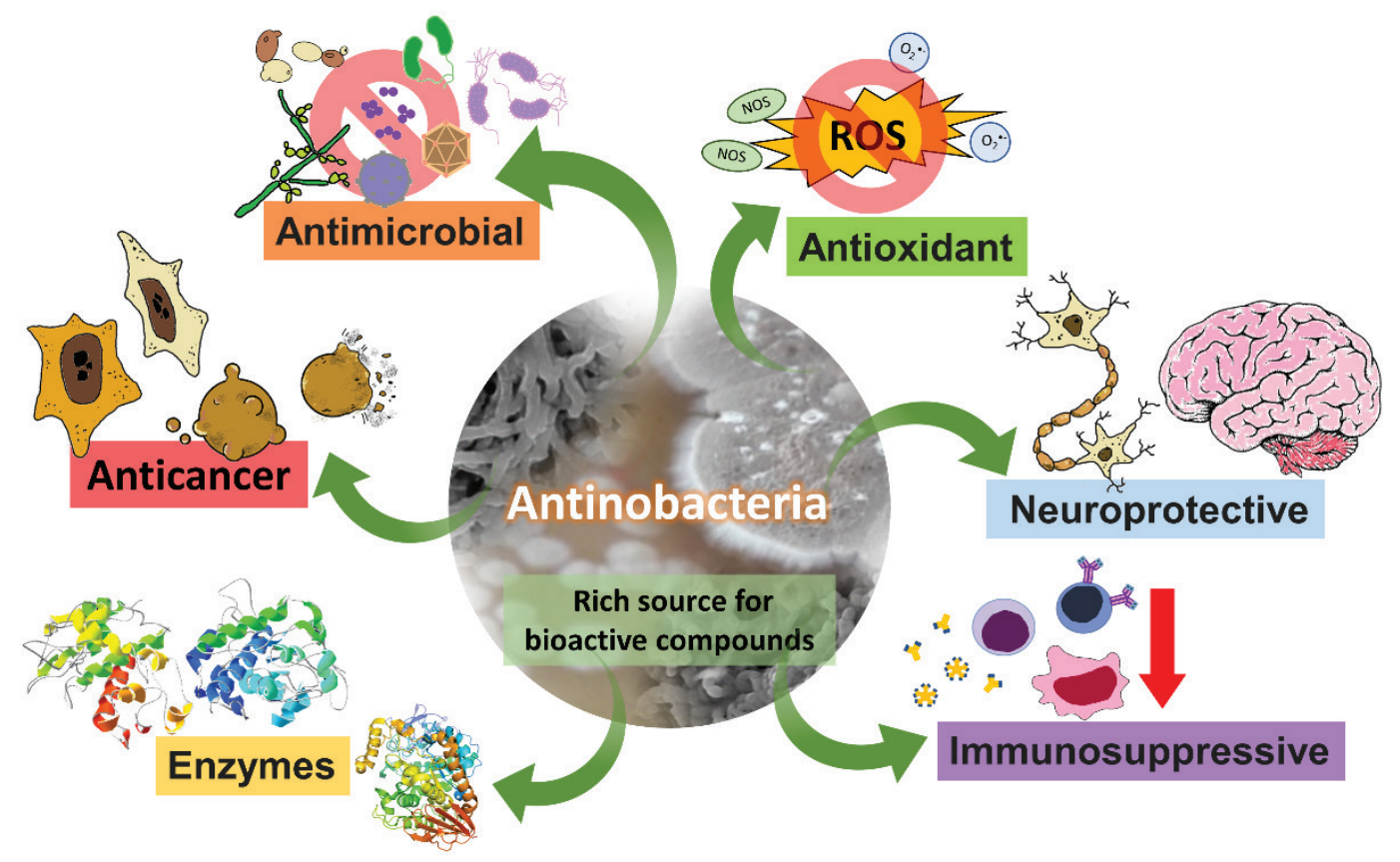

Figure 1. Actinobacteria are prolific producers for metabolites with diverse activities

The genome sequencing of Streptomyces coelicolor $\mathrm{A}(3) 2^{\mathrm{T}[69]}$ and Streptomyces avermitilis MA-4689 ${ }^{\mathrm{T}[70,71]}$ discovered that these bacteria comprise more than 20 natural product gene clusters. This number of gene clusters is much more as compared to genomes of bacteria from another phylum ${ }^{[72,73]}$. For instance, Bacillus subtilis strain $168^{\mathrm{T}}$ with three, Ralstonia solanacearum strain GMI $1000^{\mathrm{T}}$ with two ${ }^{[74]}$, and Pseudomonas aeruginosa strain $\mathrm{PA} 01^{\mathrm{T}}$ with four ${ }^{[75]}$ Pseudomonas aeruginosa strain . While most other bacteria genomes lacking any detected natural product gene clusters ${ }^{[69]}$. These reports indicated the capability to produce secondary metabolites are not evenly distributed among microbes. Moreover, multiple gene clusters encoding for alike classes of secondary metabolites have been discovered in the genomes of other Actinobacteria $^{[76,77]}$. Thus, explaining Actinobacteria are highly prolific sources of bioactive metabolites ${ }^{[78]}$ with high capacity to utilize a extensive range of compounds and create secondary metabolites with diverse chemical structures and biological activities ${ }^{[79,80]}$.

\section{Unexplored environment - The Antarctic}

The Antarctic is the area at the Earth's South Pole, contrary the Arctic region at the North Pole. The Antarctic includes the continent of Antarctica and the ice shelves, waters and island territories in the Southern Ocean situated south of the Antarctic Convergence. The area covers approximately $20 \%$ of the Southern Hemisphere, of which 5.5\% (14 million $\mathrm{km}^{2}$ ) is the surface area of the continent itself. The Antarctic is the coldest and windiest continent, it is a hostile, remote, and uninhabited area with its surrounding marine sites, provides an appropriate chance to investigate a still unexplored microbial biodiversity ${ }^{[81-87]}$. The uneven mixture of selection pressures has led to the evolution of novel biochemical adaptations and the likelihood of native species ${ }^{[88,89]}$. The production of metabolites such as antibiotics and toxins could confer a competitive survival benefit in this environment. Therefore, the investigation of poorly explored areas such as the Antarctic seemed as important region for discovering of potential novel bacteria and useful biological active metabolites ${ }^{[59,82,85,90,91]}$.

\section{Bacteria from Antarctic territories}

The information of prokaryotic biodiversity remains very sparse across Antarctica ${ }^{[82,92,93]}$. Nevertheless, in recent decades, the improvement in both culture dependent and culture-independent methodologies allow some studies focused on Signy Island were done ${ }^{[94,95,96,97,98,99]}$. This area 
act as a benchmark site within the maritime Antarctic, whose terrestrial ecosystems are demonstrative of the region ${ }^{[100]}$. Furthermore, more studies are also emerging from other sites along the Antarctic Peninsula, such as the study of the prokaryotic communities of a series of Antarctic terrestrial habitats along a latitudinal gradient as part of a larger regional microbial diversity study covering between the Falkland Islands $\left(\sim 50^{\circ} \mathrm{S}\right)$ and Mars Oasis, Alexander Island $\left(\sim 72^{\circ} \mathrm{S}\right)^{[101-103]}$. Based on the restricted habitats studied, a fairly large bacterial diversity has been reported ${ }^{[96-99,104,105]}$.

There is an agreement that spatial distinction between soil organisms is not random but displays expectable patterns over dissimilar spatial scales. The small-scale difference is found to exhibit superior diversity than large scale difference ${ }^{[106-108]}$. Small-scale difference might be more vulnerable to local environmental effects such as areas of increased substrate availability ${ }^{[109]}$. Scientists indicated that water content, organic content (loss on ignition) and total $\mathrm{N}$ showed substantial direct correlations with microbial counts from soil at 6 different sites on Signy Island, whereas $\mathrm{pH}$ exhibited an inverse association ${ }^{[94]}$. Some recent culture-independent reports have demonstrated that soil prokaryote biodiversity on Signy Island have high association with elements such as conductivity, $\mathrm{pH}$, lead and copper content. Moreover, significant overlap was reported across sites evidently affected by penguins, seals, and the existence of vegetation ${ }^{[99]}$. The direct effect of soil properties for instance soil $\mathrm{pH}$, nutrients and moisture on bacterial diversity were demonstrated $^{[110-113]}$, and remarkably these parameters also exhibited close connection to specific functional genes for instance glutamate dehydrogenase and nitrate reductase ${ }^{[102]}$.

Studies of the bacterial ecology of Antarctic soils by means of culturing dependent methods demonstrated that bacterial abundance and diversity can differ with soil factors for instance moisture, $\mathrm{pH}$, available nutrients, salinity, elevation, slope, solar radiation, and drainage ${ }^{[114]}$. Suzuki et al. (1997) ${ }^{[115]}$ isolated an obligate psychrophilic Actinobacteria, Cryobacterium psychrophilum from the Antarctica soil. This bacterium grew best at $9-12^{\circ} \mathrm{C}$ and did not grow at temperatures higher than $18^{\circ} \mathrm{C}$. While psychrophilic strains of Modestobacter multiseptatus with optimum growth temperatures of $11-13^{\circ} \mathrm{C}$ have also been isolated from transantarctic mountain soils ${ }^{[116]}$.

Normally, the early studies on the bacterial diversity of Antarctic soils were disadvantaged by the readiness of appropriate approaches. With the accessibility of DNA-based culture-independent assays, analysis of mineral soils of the Antarctic area has discovered that the soil bacterial communities have low diversity compared with temperate soils and may be dominated by a few bacterial phylotypes. Bacteria reported from the soils typically group with the phyla Actinobacteria, Acidobacteria, Bacteroidetes, Deinococcus-Thermus, Firmicutes, Cyanobacteria and Proteobacteria ${ }^{[117-119]}$. Apart from Deinococcus and Cyanobacteria, they are among the phyla normally described from non-Antarctic soils $^{[120]}$. The phyla Actinobacteria and Bacteroidetes appear to be prevalent in Antarctica while other phyla less broadly spread (e.g. Acidobacteria). Remarkably some bacteria have no close relatives demonstrating soils of the Antarctic (e.g. Ross Sea Region) are extremely potential as a natural reserve of novel and cold-adapted bacteria ${ }^{[118]}$. The closest relatives include members of the genera Arthrobacter, Brevundimonas, Leptolyngbya, Hymenobacter, Nocardioides, Sphingomonas and Sporosarcina ${ }^{[117-119]}$ all of which have been isolated from Antarctic soil.

The Barrientos Island of Antarctic is situated at $62^{\circ} 24^{\prime} \mathrm{S}$, $59^{\circ} 47^{\prime} \mathrm{W}$, north entrance to English Strait between Robert and Greenwich Islands. The north coast of the $1.5 \mathrm{~km}$ island is dominated by steep cliffs, reaching a height of nearly 70 metres, with a gentle slope down to the south coast. The eastern and western ends of the island are black sand and cobbled beaches. The western end has columnar basalt outcrops as a notable feature. The whole center of the island is covered by widespread moss carpet. Lichens Xanthoria spp., Caloplaca spp. and other crustose lichen species are present. Moreover, the green alga Prasiola crispa is prevalent. Soil samples were collected from this island and molecular identification, which was based on $16 \mathrm{~S}$ rDNA sequences analysis, discovered eight genera of Actinobacteria namely Actinomyces, Actinobacterium, an uncultured Actinomycete, Streptomyces, Leifsonia, Frankinea, Rhodococcus and Mycobacterium. The uncultured Actinomyces sp. and Rhodococcus sp. appear to be the prominent genera of Actinobacteria in Barrientos Island soil ${ }^{[121]}$. Molecular methods were applied to investigate correlations between actinobacteria abundance and environmental features, for instance vegetation and type of rookery. There was a substantial positive association between type of rookery and the abundance of actinobacteria; soil samples collected from active chinstrap penguin rookeries had the highest actinobacteria abundance. Vegetation type, for instance moss, which could provide a microhabitat for bacteria did not associate significantly with actinobacteria abundance ${ }^{[121]}$.

In Barrientos Island, the selective isolation of culturable bacteria using 12 different isolation media were performed and total 96 bacteria isolates were isolated with 39 and 57 isolates belonged to phylum Actinobacteria and Proteobacteria, respectively. Through 16S rRNA gene analysis, 13 (Arthrobacter, Brevibacterium, Demetria, Gordonia, Rhodococcus, Janibacter, Leifsonia, Dermacoccus, Kocuria, Lapillicoccus, Micromonospora, Microbacterium, Nocardioides) and 8 (Bradyrhizobium, Caulobacter, Sphingomonas, Methylobacterium, Paracoccus, Ralstonia, Rhizobium, Staphylococcus) different genera of Actinobacteria and Proteobacteria, respectively were discovered ${ }^{[122,123]}$. Comparatively Actinobacteria (13 genera) had substantial higher diversity than Proteobacteria ( 8 genera $)^{[122,123]}$, hence showed that Actinobacteria are proficient to prosper in an extensive range of diverse soil environments, and they could resist the pressure of harsh environment as they could persist in the viable but inactive state for a extended time with form of spore ${ }^{[124]}$. Their extensive disseminations in Antarctic suggest that their dispersals are extremely endemic, 
predominantly in soil and sediment ${ }^{[12,125]}$. Therefore, allowing the bio-prospecting of bacteria from sampling soil from widespread array of geographic sites, such as the Antarctic areas to be benefitted. Results showed that Streptomyces agar (SA) was the most suitable medium for isolating actinobacteria from soil of Barrientos Island with $54 \%$ isolation rate, while starch casein agar (SCA) was the most suitable medium to isolate proteobacteria with $19 \%$ isolation rate ${ }^{[122,123]}$.

Furthermore, researchers studied actinobacteria and proteobacteria isolates from Barrientos Island for ability of producing antibacterial and antifungal secondary metabolites $^{[122,123]}$. By means of high-throughput screening models, about $23 \%, 9 \%, 6 \%$ and $1 \%$ of isolates inhibited growth of Candida albicans ATCC $10231^{\mathrm{T}}$, Staphyloccoccus aurues ATCC $51650^{\mathrm{T}}$, methicillinresistant S. aurues (MRSA) ATCC BAA-44 ${ }^{\mathrm{T}}$ and Pseudomonas aeruginosa ATCC $10145^{\mathrm{T}}$, respectively. A total 34 bioactive isolates were isolated and categorized into 13 genera, particularly 9 genera were actinobacteria. The high bioactivities of actinobacteria isolates (38\%) as compared to proteobacteria isolates $(25 \%)$ in this study $^{[122,123]}$ showed that Actinobacteria still remain as the better source for bioprospecting of novel bioactive metabolites owing to their tremendous capability to produce secondary metabolites with varied chemical structure and biological activities ${ }^{[79,80,126]}$. These findings provided vital baseline data that Barrientos Island is a good source of isolation for bioactive actinobacteria and proteobacteria with good antibacterial and antifungal metabolites $^{[122,123]}$.

In Barrientos Island, the application of the polyphasic taxonomic such as on the basis of phylogenetic, chemotaxonomic, phenotypic and signature nucleotide pattern of the 16S rRNA gene, these results indicated that strain $39^{\mathrm{T}}$ is unlike all the genera in the family Dermacoccaceae. Hence, it is recommended that strain $39^{\mathrm{T}}$ to be categorized in a novel genus in the family Dermacoccaceae, as Barrientosiimonas gen. nov., the type species of which is Barrientosiimonas humi gen. nov., sp. nov. The strain was named after Barrientos Island, the origin of the sampling site ${ }^{[127]}$.

\section{Bacteria as source of new natural products}

The natural products have been demonstrated to be the richest source for discovery of novel bioactive compounds ${ }^{[128]}$. Previously, the majority bioactive products of microbial origin obtained from few taxonomic groups and mainly terrestrial environments ${ }^{[42,48]}$. In these decades, microbial natural products research inspired the progress of integrated methods merging specific isolation methods and the access to geographically diverse sources and to different ecological niches ${ }^{[128]}$. Lately the advancement of technologies enables other initiatives like targeting the exploitation of the metabolic potential of environmental gene libraries without undertaking the need of culturing microbes ${ }^{[129-131]}$.

The microbial secondary metabolites comprise of antitumor agents, antibiotics, pesticides, enzyme inhibitors, toxins, and pigments. The biosynthesis of these metabolites is usually coded by genes clusters on chromosomal DNA and irregularly on plasmid $\mathrm{DNA}^{[132]}$. The discovery of new classes of antibiotics are vital to fight the increased occurrence of multiple resistances among pathogens to the available drugs presently in clinical use ${ }^{[133]}$. The utmost producers of natural product antibiotics are Actinobacteria as nearly two thirds of natural products have been derived from Actinobacteria ${ }^{[20]}$, with streptomycetes accountable for more than $80 \%$ of them.

The phylum Actinobacteria signify a significant constituent of the microbial population in most soils ${ }^{[134-138]}$; such as the Antarctic region ${ }^{[117-119,139]}$. Also, Actinobacteria present in rhizosphere soil were reported for discovery of antimicrobial agents and other useful metabolites ${ }^{[140-151]}$. The genus Streptomyces exhibited potential as bio-control agent of commercial crops against fungal pathogens ${ }^{[17,152]}$. Moreover, Streptomyces spp. derived from grapes exhibited antifungal activity that is pathogenic to fungi and yeast from the same habitat ${ }^{[153]}$. While the genus Arthrobacter, a pervasive genus repeatedly discovered in Antarctic and Arctic areas is recognized for secondary bioactive metabolite production and for bioconversions ${ }^{[154,155]}$. Rojas et al. (2009) ${ }^{[128]}$ examined Antarctic bacteria for creation of novel metabolites discovered a novel molecules associated to cyclic thiazolyl peptides active on gram positive pathogens produced by Arthrobacter agilis derived from Lake Hoare and Lake Fryxell from the McMurdo Dry Valley area in Antartic ${ }^{[128]}$.

The Antarctic $\gamma$ - and $\beta$-Proteobacteria strains R-12535 and R-7687 derived from Lake Reid in the Larsemann Hills and Lake Hoare in the McMurdo Dry Valleys produced bioactive metabolites that inhibited the growth of gram positive and negative pathogens such as $E$. coli and $S$. aureus ${ }^{[128]}$. Moreover, the MS spectra of bioactive metabolites obtained from the $\gamma$ - and $\beta$-Proteobacteria strains R-12535 and R-7687 indicated no relatedness with any known compounds, suggesting a chemical novelty related to the bioactivity of these Antarctic bacteria. These studies demonstrated the high occurrences of antimicrobial activities discovered from Antarctic bacteria, which exhibited them as a prolific source of antimicrobial agents $^{[42,62,156]}$. These findings support the notion that bacteria from Antarctic habitats comprise a rich metabolic diversity and the production of antimicrobial agents could provide a competitive benefit in this situation ${ }^{[157]}$.

Other than antimicrobial agents, bacteria such as Actinobacteria produced enzymes that are vital and extensively used in medical therapy, bio-organic chemistry, molecular biology, detergent manufacturing, food processing, the textile and pharmaceutical industries ${ }^{[158]}$. For instance, Thermophilic ThermoActinomyces candidus could yield extracellular enzyme keratinase that could degrade wool $^{[159]}$. The antimicrobial agents and keratindegrading producing Actinobacteria (Streptomyces, Nocardioides, Saccharomonospora, Nonomuraea and Nocardiopsis) have been utilized to transformed poultry farm feather waste by composting into pathogen-free 
and odourless bio-fertilizer with complete biological degradation $^{[160]}$.

Crawford (1978) $)^{[161]}$ reported that streptomycetes can decay lignin by producing the enzyme lignin peroxidase. The extracellular lignin peroxidase derived from Streptomyces viridosporus has been studied $^{[162]}$ and it was the first report of a lignin peroxidase from a bacterium. In nature, lignin physically covers cellulose to form lignocellulose (65\% cellulose, 25\% lignin, and small quantities of hemicellulose glucans), and is resilient to degradation by most microorganisms. Streptomyces viridosporus T7A could depolymerizes lignin while degrading cellulose $^{[161]}$ and generates a modified water-soluble, acid-precipitable polymeric lignin (APPL) as a key lignin degradation product ${ }^{[163]}$. Pasti et al. $(1990)^{[164]}$ revealed novel Streptomyces strains, the $S$. rochei and S. chromofuscus that were discovered to be superior or equivalent in lignocellulose-degrading capability to Streptomyces viridosporus T7A.

The enzyme chitinase were discovered from the culture filtrate of Streptomyces cinereorube ${ }^{[165]}$. The enzyme was inhibited by $\mathrm{Ag}^{+}, \mathrm{Hg}^{+}, \mathrm{Hg}^{2+}$ and $\rho$-chloromercuribenzoate. This enzyme is stable in $\mathrm{pH}$ range 4.0-10.0 and the optimum $\mathrm{pH}$ and temperature for chitinase activity were 4.5 and $50^{\circ} \mathrm{C}$, respectively. Gomes et al. (2000) ${ }^{[166]}$ reported that Streptomyces spp. obtained from a Brazilian forest soil exhibited exceptional endochitinase activity and very active against three phytopathogenic fungi, namely Fusarium solani, Magnaphorte grisea and Aspergillus parasiticus.

Streptomyces ipomoea CECT3341 and S. scabies CECT3340 in liquid culture produces great levels of enzyme mannanase ${ }^{[167]}$. The potential of mannanase enzyme in refining the bleachability of pine kraft pulp was demonstrated. With bio-bleaching examinations by means of treatment of the enzyme to result in the release of chromophoric and color material from the pine kraft pulp, together with an increase in pulp brightness and an absence of differences in the viscosity values.

Berens et al. (1996) ${ }^{[168]}$ effectively obtained the enzyme endoxylanases from the thermophilic actinobacteria Microtetraspora flexuosa SIIX. These thermostable enzymes reported to have optimal activities at $\mathrm{pH} 6.0$ and $80^{\circ} \mathrm{C}$. The hydrolysis of hemicellulose generated mostly xylobiose and xylotriose, the latter will be hydrolysed to xylobiose and xylose. Researchers demonstrated the production of endoxylanase from Streptomyces noboritoensis ${ }^{[169]}$. Moreover, a cellulasefree and endoxylanase-producing streptomycete, Streptomyces thermocoprophilus sp. nov. was discovered by Kim et al. $(2000)^{[170]}$.

Busch and Stutzenberger (1997 $)^{[171]}$ discovered the Thermomonospora fusca, a facultative thermoalkalophilic Actinobacteria that produces an extracellular $\alpha$-amylase which generates maltotriose as the key product. The optimum $\mathrm{pH}$ and temperature for the amylase activity were 6.0 and $65^{\circ} \mathrm{C}$, respectively. The enzyme activity was not blocked by the addition of glucose due to the preference of the Actinobacteria for maltotriose.

Pasti and Belli (1985) ${ }^{[172]}$ reported isolation of Streptomyces sp. and Micromonospora sp. from termite gut whereby these strains produce enzyme cellulose that contributed to their cellulolytic activity. A total of 4 different termites were reported for the isolation of cellulolytic Actinobacteria, namely Armitermes, Macrotermes, Odontotermes and Microcerotermes spp. All Actinobacteria strains effectively degraded both soluble and insoluble cellulose with some shown persistent activity up to a week. Waldron et al. (1986) ${ }^{[173]}$ reported the isolation of Microbispora bispora from soil samples of hot springs, geysers and composts was found to grow at $55^{\circ} \mathrm{C}$ and create thermo-stable extracellular endoglucanase in good concentration with broad $\mathrm{pH}$ range of 5.5-7.2.

All these reports indicated the practicality of various enzymes produced by various bacteria such as Actinobacteria. The value of bacteria in the production of enzymes is heightened by their comparatively high produces, cost efficiency and susceptibility to genetic manipulation. These enzymes enabled bacteria to have a key role in numerous areas for instance the biodegradation of plant litter especially the recalcitrant lignocellulose component ${ }^{[174]}$ and the decomposition of soil organic matter ${ }^{[175]}$.

\section{CONCLUSION}

As a conclusion, the research of microbial diversity and the isolation of novel microorganisms signify a key chance for developments in biology ${ }^{[67,176-181]}$. The search and discovery of novel microbes that produce new useful secondary metabolites remains important in the fight against antibiotic resistant pathogens ${ }^{[182]}$, and new emerging diseases ${ }^{[183-185]}$.

\section{Author Contributions}

N-SAM, SHW, H-LS, LT-HT and JW-FL performed the literature search, critical review and performed the writing of this review. Guidance, support, and proofreading were contributed by AD, SR and VL. N-SAM and VL founded the review writing project.

\section{References}

1. Cowan DA. The marine biosphere: A global resource for biotechnology. Trends Biotechnol 1997; 15: 129-131.

2. Costanza R, d'Arge R, de Groot R, et al. The value of the world's ecosystem services and natural capital. Nature 1997; 387: 253-260.

3. Bérdy J. Thoughts and facts about antibiotics: Where we are now and where we are heading. J Antibiot 2012; 65(8): 385

4. Goodfellow M, Williams ST and Mordarski M. (Eds.) (1988) Actinomycetes in Biotechnology. London: Academic Press.

5. Copp BR. Antimycobacterial natural products. Nat Prod Rep 2003; 20: 535-557.

6. Strohl WR. Antimicrobials. In Microbial diversity and bioprospecting 2004; 336-355. Edited by AT Bull. Washington: ASM Press. 
7. McCoy M. Setting course for prosperity. Chem Eng News 1999; 77: 29-34.

8. Reisch MS. The fix is in: Cartels beware. Chem Eng News 2000; 78: $11-14$.

9. Zeikus JG, Jain MK and Elankovan P. Biotechnology of succinic acid production and markets for derived industrial products. Appl Microbiol Biot 1999; 51: 545-552.

10. Shaw NM, Lehner B, Fuhrmann M, et al. Biotin production under limiting growth conditions by Agrobacterium/Rhizobium HK4 transformed with a modified Escherichia coli bio operon. J Ind Microbiol Biot 1999; 22: 590-599.

11. Arul Jose P and Jebakumar SRD. Non-streptomycete actinomycetes nourish the current microbial antibiotic drug discovery. Front Microbiol 2013; 4: 240.

12. Ser H-L, Law JW-F, Chaiyakunapruk N, et al. Fermentation conditions that affect clavulanic acid production in Streptomyces clavuligerus: A systematic review. Front Microbiol 2016; 7: 522.

13. Tan LT-H, Lee L-H and Goh B-H. The bioprospecting of anti-Vibrio Streptomyces species: Prevalence and applications. Prog Microbes Mol Biol 2019; 2(1): a0000034.

14. Das S, Ward LR, and Burke C. Prospects of using marine actinobacteria as probiotics in aquaculture. Appl Microbiol Biotechnol 2008; 81(3): 419-429.

15. Tan LT-H, Chan K-G, Lee L-H, et al. Streptomyces bacteria as potential probiotics in aquaculture. Front Microbiol 2016; 7: 79.

16. Kemung HM, Tan LT-H, Khan TM, et al. Streptomyces as a prominent resource of future anti-MRSA drugs. Front Microbiol 2018; 9: 2221.

17. Law JW-F, Ser H-L, Khan TM, et al. The potential of Streptomyces as biocontrol agents against the rice blast fungus, Magnaporthe oryzae (Pyricularia oryzae). Front Microbiol 2017; 8: 3

18. Tan, LT-H, Lee L-H, and Goh B-H. Critical review of fermentation and extraction of anti-Vibrio compounds from Streptomyces. Prog Microbes Mol Biol 2020; 3(1): a0000051

19. Suzuki K, Goodfellow M and O’Donnell AG. Cell envelopes and classification. In Handbook of New Bacterial Systematics 1993; 195 250. Edited by M Goodfellow, and AG O'Donnell. London: Academic Press.

20. Bérdy J. Are actinomycetes exhausted as a source of secondary metabolites? Biotechnologia 1994; 7(8): 13-34.

21. Castillo UF, Strobel GA, Ford EJ, et al. Munumbicins, wide-spectrum antibiotics produced by Streptomyces NRRL 30562, endophytic on Kennedia nigriscans. Microbiol 2002; 148: 2675-2685.

22. Blunt JW, Copp BR, Munro MHG, et al. Marine natural products. Nat Prod Rep 2003; 20: 1-48

23. Ser H-L, Palanisamy UD, Yin W-F, et al. Streptomyces malaysiense sp. nov.: A novel Malaysian mangrove soil actinobacterium with antioxidative activity and cytotoxic potential against human cancer cell lines. Sci Rep 2016; 6(1): 1-12.

24. Law JW-F, Chan K-G, He Y-W, et al. Diversity of Streptomyces spp. from mangrove forest of Sarawak (Malaysia) and screening of their antioxidant and cytotoxic activities. Sci Rep 2019; 9(1): 1-15.

25. Tan LT-H, Chan C-K, Chan K-G, et al. Streptomyces sp. MUM256: A Source for apoptosis inducing and cell cycle-arresting bioactive compounds against colon cancer cells. Cancers (Basel) 2019; 11(11): 1742 .

26. Ser H-L, Yin W-F, Chan K-G, et al. Antioxidant and cytotoxic potentials of Streptomyces gilvigriseus MUSC $26^{\mathrm{T}}$ isolated from mangrove soil in Malaysia. Prog Microbes Mol Biol 2018; 1(1): a0000002.

27. Tapiolas DM, Roman M and Fenical W. Octalactins A and B: Cytotoxic eight-membered-ring lactones from a marine bacterium, Streptomyces sp. J Am Chem Soc 1991; 113: 4682-4683.

28. Ser H-L, Tan LT-H, Law JW-F, et al. Focused review: Cytotoxic and antioxidant potentials of mangrove-derived Streptomyces. Front Microbiol 2017; 8: 2065.

29. Wrigley SK. Pharmacologically active agents of microbial origin. In Microbial diversity and bioprospecting 2004; 356-374. Edited by AT Bull. Washington: ASM Press.

30. Tan LTH, Mahendra CK, Yow YY, et al. Streptomyces sp. MUM273b: A mangrove $\square$ derived potential source for antioxidant and UVB radiation protectants. MicrobiologyOpen 2019: e859.

31. Kemung HM, Tan LT-H, Chan K-G, et al. Antioxidant activities of Streptomyces sp. strain MUSC 14 from mangrove forest soil in Malaysia. Biomed Res Int 2020; 2020: 6402607.

32. Law JW-F, Ser H-L, Ab Mutalib N-S, et al. Streptomyces monashensis sp. nov: A novel mangrove soil actinobacterium from East Malaysia with antioxidative potential. Sci Rep 2019; 9(1): 3056.

33. Kemung HM, Tan LT-H, Chan K-G, et al. Investigating the antioxidant potential of Streptomyces sp. MUSC 11 from mangrove soil in Malaysia. Prog Drug Discov Biomed Sci 2019; 2(1): a0000033.

34. Tan LT-H, Chan K-G, Chan CK, et al. Antioxidative potential of a Streptomyces sp. MUM292 isolated from mangrove soil. Biomed Res Int 2018; 2018: 4823126

35. Kemung HM, Tan LT-H, Chan K-G, et al. Antioxidant activities of Streptomyces sp. strain MUSC 14 from mangrove forest soil in Malaysia. Biomed Res Int 2020; 2020: 6402607.

36. Azman A-S, Othman I, Fang C-M, et al. Antibacterial, anticancer and neuroprotective activities of rare Actinobacteria from mangrove forest soils. Indian J Microbiol 2017; 57(2): 177-187.

37. Ser H-L, Tan LT-H, Palanisamy UD, et al. Streptomyces antioxidans sp. nov., A novel mangrove soil actinobacterium with antioxidative and neuroprotective potentials. Front Microbiol 2016; 7: 899

38. Takahashi Y, Seino A, Iwai Y, et al. Taxonomic study and morphological differentiation of an actinomycete genus, Kitasatospora. Zentralbl
Bakteriol 1999; 289: 265-284.

39. Schrempf H. Recognition and degradation of chitin by streptomycetes Antonie Leeuwenhoek 2001; 79: 285-289.

40. Ser H-L, Tan W-S, Cheng H-J, et al. Draft genome of amylolytic actinobacterium, Sinomonas humi MUSC $117^{\mathrm{T}}$ isolated from intertidal soil. Mar Genomics 2015; 24: 209-210.

41. Ser H-L, Tan W-S, Cheng H-J, et al. Draft genome of starch-degrading actinobacterium, Microbacterium mangrovi MUSC $115^{\mathrm{T}}$ isolated from intertidal sediments. Prog Drug Discov Biomed Sci 2018; 1(1): a0000005.

42. Bérdy J. Bioactive microbial metabolites (review). J Antibiot 2005; 58 : $1-26$.

43. Bredholt H, Fjaerik E, Johnsen G, et al. Actinomycetes from Sediments in the Trondheim Fjord, Norway: Diversity and Biological Activity. Mar Drugs 2008; 6: 12-24.

44. Barakate $\mathrm{M}$, Ouhdouch $\mathrm{Y}$, Oufdou $\mathrm{K}$ et al. Characterization of rhizospheric soil streptomycetes from Moroccan habitats and their antimicrobial activities. World J Microbiol Biotechnol 2002; 18: 49-54.

45. Law JW-F, Pusparajah P, Ab Mutalib N-S, et al. A review on mangrove actinobacterial diversity: The roles of Streptomyces and novel species discovery. Prog Microbes Mol Biol 2019; 1(1): a0000024

46. Ser H-L, Zainal N, Palanisamy UD, et al. Streptomyces gilvigriseus sp. nov., A novel actinobacterium isolated from mangrove forest soil. Antonie Van Leeuwenhoek, 2015; 107(6): 1369-1378.

47. Saadoun I and R Gharaibeh. The Streptomyces flora of Badia region of Jordan and its potential as a source of antibiotic-resistant bacteria. J Arid Environ 2003; 53: 365-371.

48. Lam KS. New aspects of natural products in drug discovery. Trends Microbiol 2007; 15: 279-289.

49. Ser H-L, Ab Mutalib N-S, Yin W-F, et al. Genome sequence of Streptomyces antioxidans MUSC $164^{\mathrm{T}}$ isolated from mangrove forest. Prog Microbes Mol Biol 2018; 1(1): a0000001.

50. Ser H-L, Tan W-S, Mutalib N-SA, et al. Genome sequence of Streptomyces gilvigriseus MUSC $26^{\mathrm{T}}$ isolated from mangrove forest. Braz J Microbiol 2018; 49(2): 207-209.

51. Newman DJ and Cragg GM. Natural products as sources of new drugs over the last 25 years. J Nat Prod 2007; 70: 461-477.

52. Ser H-L, Chan K-G, Tan W-S, et al. Complete genome of mangrovederived anti-MRSA streptomycete, Streptomyces pluripotens MUSC 135 ${ }^{\mathrm{T}}$. Prog Microbes Mol Biol 2018; 1(1): a0000004.

53. Ser H-L, Tan W-S, Yin W-F, et al. Whole genome sequence of Streptomyces humi strain MUSC $119^{\mathrm{T}}$ isolated from intertidal soil. Prog Drug Discov Biomed Sci 2019; 2(1): a0000020.

54. Thakur D, Yadav A, Gogoi BK, et al. Isolation and screening of Streptomyces in soil of protected forest areas from the states of Assam and Tripura, India, for antimicrobial metabolites. J Mycol Med 2007; 17 : 242-249.

55. Ser H-L, Law J-F, Tan W-S, et al. Whole genome sequence of Streptomyces colonosanans strain MUSC $93 \mathrm{~J}^{\mathrm{T}}$ isolated from mangrove forest in Malaysia. Prog Microbes Mol Biol 2020; 3(1): a0000061.

56. Okazaki $\mathrm{T}$ and Naito $\mathrm{A}$. Studies on actinomycetes isolating from Australian soil. In: Szabo G, Biro S and Goodfellow M, editors. Biological biochemical and biomedical aspects of actinomycetes. 1986; 739-741. Budapest: Akademiai Kiado.

57. Nolan $\mathrm{R}$ and Cross $\mathrm{T}$. Isolation and screening of actinomycetes. In Goodfellow M, Williams ST and Mordarski M (ed). Actinomycetes in biotechnology. 1988; 1-32. London: Academic Press.

58. Ser H-L, Tan W-S, Ab Mutalib N-S, et al. Draft genome sequence of mangrove-derived Streptomyces sp. MUSC 125 with antioxidant potential. Front Microbiol 2016; 7: 1470.

59. Moncheva P, Tishkov S, Dimitrova N, et al. Characteristics of soil actinomycetes from Antarctica. J Culture Collections 2002; 3: 3-14

60. Kemung HM, Tan LT-H, Chan K-G, et al. Streptomyces sp. strain MUSC 5 from mangrove forest in Malaysia: Identification, antioxidant potentia and chemical profiling of its methanolic extract. Prog Microbes Mol Biol 2020; 3(1): a0000087.

61. Ser H-L, Tan W-S, Ab Mutalib N-S, et al. Genome sequence of Streptomyces mangrovisoli MUSC $149^{\mathrm{T}}$ isolated from intertidal sediments. Braz J Microbiol 2018; 49(1): 13-15.

62. Lazzarini A, Toppo CG and Marinelli F. Rare genera of actinomycetes as potential producers of new antibiotics. Antonie Leeuwenhoek 2000; 79: $399-405$.

63. Donadio S, Monciardini P, Alduina R, et al. Microbial technologies for the discovery of novel bioactive metabolites. J Biotechnol 2002; 99 : 187-198.

64. Takahashi $Y$ and Ōmura S. Isolation of new actinomycete strains for the screening of new bioactive compounds. J Gen Appl Microbiol 2003; 49 . $141-154$.

65. Donadio S, Carrano L, Brandi L, et al. Targets and assays for discovering novel antibacterial agents. J Biotechnol 2002; 99: 175-185.

66. Bull AT. Microbial Diversity and Bioprospecting. 2004. Washington: ASM Press.

67. Harvey A. Strategies for discovering drugs from previously unexplored natural products. Drug Discov Today 2000; 5: 294-300.

68. Ward AC and Goodfellow M. Phylogeny and functionality: Taxonomy as road map to genes. In Microbial diversity and bioprospecting 2004 288-313. Edited by AT Bull. Washington: ASM Press.

69. Bentley SD, Chater KF, Cerdeno-Tarraga AM, et al. Complete genome sequence of the model actinomycete Streptomyces coelicolor A3(2). Nature 2002; 417: 141-147.

70. Ōmura S, Ikeda H, Ishikawa J, et al. Genome sequence of an industrial microorganism Streptomyces avermitilis: Deducing the ability of producing secondary metabolites. P Natl Acad Sci USA 2001; 98: $12215-12220$. 
71. Ikeda $\mathrm{H}$, Ishikawa $\mathrm{J}$, Hanamoto $\mathrm{A}$, et al. Complete genome sequence and comparative analysis of the industrial microorganism Streptomyces avermitilis. Nat Biotechnol 2003; 21: 526-531.

72. Ser H-L, Tan W-S, Ab Mutalib N-S, et al. Genome sequence of Streptomyces pluripotens MUSC $135^{\mathrm{T}}$ exhibiting antibacterial and antioxidant activity. Mar Genomics 2015; 24: 281-283.

73. Law JW-F, Tan K-X, Wong SH, et al. Taxonomic and characterization methods of Streptomyces: A review. Prog Microbes Mol Biol 2018; 1(1): a0000009.

74. Salanoubat M, Genin S, Artiguenave F, et al. Genome sequence of the plant pathogen Ralstonia solanacearum. Nature 2002; 415: 497-502.

75. Stover CK, Pham XQ, Erwin AL, et al. Complete genome sequence of Pseudomonas aeruginosa PA01, an opportunistic pathogen. Nature 2000; 406: 959-964.

76. Cole ST, Brosch R, Parkhill J, et al. Deciphering the biology of Mycobacterium tuberculosis from the complete genome sequence. Nature 1998; 393: 537-544

77. Sosio M, Bossi E, Bianchi A, et al. Multiple peptide synthetase gene clusters in actinomycetes. Mol Gen Genet 2000; 264: 213 221.

78. Péric-Concha $\mathrm{N}$ and Long PF. Mining the microbial metabolome: a new frontier for natural product lead discovery. Drug Discov Today 2003; 8: 1078-1084.

79. Woo PCY, Lau SKP, Huang Y, et al. Genomic evidence for antibiotic resistance genes of actinomycetes as origins of antibiotic resistance genes in pathogenic bacteria simply because actinomycetes are more ancestral than pathogenic bacteria. Med Hypotheses 2006; 67: 1297-1304.

80. Arasu VM, Duraipandiyan V, Agastian P, et al. Antimicrobial activity of Streptomyces spp. ERI-26 recovered from Western Ghats of Tamil Nadu. J Mycol Med 2008; 18: 147-153.

81. Tindall BJ, Brambilla E, Steffen M, et al. Cultivatable microbia biodiversity: Gnawing at the Gordian knot. Environ Microbiol 2000; 2 : 310-318.

82. Tindall BJ. Prokaryotic diversity in the Antarctic: The tip of the iceberg. Microb Ecol 2004; 47: 271-283.

83. Brambilla E, Hippe H, Hagelstein A, et al. $16 \mathrm{~S}$ rDNA diversity of cultured and uncultured prokaryotes of a mat sample from Lake Fryxell, McMurdo Dry Valleys, Antarctica. Extremophiles 2001; 5: 23-33.

84. Van Trappen S, Mergaert J, Van Eygen S, et al. Diversity of 746 heterotrophic bacteria isolated from microbial mats from ten Antarctic lakes. Syst Appl Microbiol 2002; 25: 603-610.

85. Marinelli F, Brunati M, Sponga F, et al. Biotechnologica exploitation of heterotrophic bacteria and filamentous fungi isolated from benthic mats of Antarctic lakes. In: Kurtböke I, Swings J. (Eds.), In Microbial Genetic Resources and Biodiscovery. 2004; 163-184. Queensland: Queensland Complete Printing Services.

86. Taton A, Grubisic S, Brambilla E, et al. Cyanobacterial diversity in natural and artificial microbial mats of Lake Fryxell (McMurdo Dry Valleys, Antarctica): A morphological and molecular approach. Appl Environ Microbiol 2003; 69, 5157-5169.

87. Taton A, Grubisic S, Ertz, D, et al. Polyphasic study of Antarctic cyanobacterial strains. J Phycol 2006; 42: 1257-1270.

88. Ellis-Evans JC and Walton D. The process of colonization in Antarctic terrestrial and freshwater ecosystems Proc NIPR Symp. Polar Biol 1990; 3: 151-163.

89. Vincent WF. Evolutionary origins of Antarctic microbiota: Invasion, selection and endemism. Antarct. Sci. 2000; 12: 374 385 .

90. Tindall BJ, Kämpfer P, Euzéby JP, et al. Valid publication of names of prokaryotes according to the rules of nomenclature: Past history and current practice. Int J Syst Evol Microbiol 2006; 56: 2715-2720.

91. Bull AT and Stach JE. Marine actinobacteria: New opportunities for natural product search and discovery. Trends Microbiol 2007; 15: 491-499.

92. Wall DH. Biodiversity and ecosystem functioning in terrestrial habitats of Antarctica. Antarct Science 2005; 17: 523-531.

93. Steven B, Léveillé R, Pollard WH, et al. Microbial ecology and biodiversity in permafrost. Extremophiles 2006; 10: 259-267.

94. Bailey AD and Wynn-Williams DD. Soil microbiology studies at Signy Island, South Orkney Islands. Brit Antarct B 1982; 51: $167-191$

95. Wynn-Williams DD. Microbial colonization processes in Antarctic fellfield soils e an experimental overview. Proceedings of the NIPR Symposion on Polar Biology 1990; 3: 164-178.

96. Pearce DA. Bacterioplankton community structure in a maritime Antarctic Oligotrophic Lake during a period of Holomixis, as determined by denaturing gradient gel electrophoresis (DGGE) and Fluorescence in Situ Hybridization (FISH). Microbial Ecol 2003; 46: 92-105.

97. Pearce DA. The structure and stability of the bacterioplankton community in Antarctic freshwater lakes, subject to extremely rapid environmental change. FEMS Microbiol Ecol 2005; 53: $61-72$.

98. Moosvi SA, McDonald IR, Pearce DA, et al. Molecular detection and isolation from Antarctica of methylotrophic bacteria able to grow with methylated sulfur compounds. Syst Appl Microbiol 2005; 28: 541-554

99. Chong CW, Dunn MJ, Convey P, et al. Environmental influences on bacterial diversity of soils from Signy Island, maritime
Antarctic. Polar Biol 2009; 32: 1571-1582.

100. Smith RIL. Signy Island as a paradigm of biological and environmental change in Antarctic terrestrial ecosystems. In: Kerry, KR, Hempel, G, (Eds.), Antarctic Ecosystems Ecological Change and Conservation 1990; 32-50. Berlin: Springer-Verlag.

101. Yergeau E, Bokhorst S, Huiskes AHL, et al. Size and structure of bacterial, fungal and nematode communities along an Antarctic environmental gradient. FEMS Microbiol Ecol 2007; 59: 436-451.

102. Yergeau E, Newsham KE, Pearce DA, et al. Patterns of bacteria diversity across a range of Antarctic terrestrial habitats. Environ Microbiol 2007; 9: 2670-2682.

103. Yergeau E, Schoondermark-Stolk SA, Brodie EL, et al. Environmental microarray analyses of Antarctic soil microbial communities. ISME J 2009; 3: 340-351.

104. Lee L-H, Letchumanan V, Ab Mutalib N-S. Microbial communiry diversity in the soil of Barrientos Island estimated by RAPD and Biolog Ecoplate Methods. Prog Microbes Mol Biol 2020; 3(1): a0000046.

105. Holdgate MW. Life sciences: Terrestrial ecosystem in Antarctic. Philos T Roy Soc B 1977; 279: 5-25.

106. Weins JA. Spatial scaling in ecology. Funct Ecol 1989; 3: 385-397.

107. Ettema CH and Wardle DA. Review: Spatial soil ecology. Trends Ecol Evol 2002; 17: 177-183.

108. Fraschetti S, Terlizzi A, Benedetti-Cecchi L. Patterns of distribution of marine assemblages from rocky shores: Evident of relevant scales of variation. Mar Ecol Prog Ser 2005; 296: 13-29.

109. Horner-Devine MC, Carney KN and Bohannan BJM. Review: An ecological perspective on bacterial biodiversity. P Roy Soc Lond B 2004; 271: 113-122.

110. Barrett JE, Virginia RA, Hopkins DW, et al. Terrestrial ecosystem processes of Victoria Land, Antarctica. Soil Biol Biochem 2006; 38: 3019-3034

111. Barrett JE, Virginia RA, Wall DH, et al. Co-variation in soil biodiversity and biogeochemistry in northern and southern Victoria Land, Antarctica. Antarct Sci 2006; 18: 535-548.

112. Aislabie JM, Jordan S and Barker GM. Relation between soil classification and bacterial diversity in soils of the Ross Sea region, Antarctica. Geoderma 2008; 144: 9-20.

113. Aislabie J, Jordan S, Ayton J, et al. Bacterial diversity associated with ornithogenic soil of the Ross Sea region, Antarctica. Can J Microbiol 2009; 55: 21-36.

114. Cameron RE, King J and David CN. Microbiology, ecology and microclimatology of soil sites in Dry Valleys of Southern Victoria Land, Antarctica. In: Holdgate MW, (Ed.), Antarctic Ecology 1970; 2: 702-716.

115. Suzuki K-I, Sasaki J, Uramoto M, et al. Cryobacterium psychrophilum gen. nov., sp. nov., nom. rev., comb. nov., an obligately psychrophilic actinomycete to accommodate "Curtobacterium psychrophilum" Inoue and Komagata 1976. Int J Syst Bacteriol 1997; 47: 474-478.

116. Mevs U, Stackebrandt E, Schumann P, et al. Modestobacter multiseptatus gen. nov., sp. nov., A budding actinomycete from soils of the Asgard Range (transantarctic mountains). Int J Syst Evo Microbiol 2000; 50: 337-346.

117. Saul DJ, Aislabie JM, Brown CE, et al. Hydrocarbon contamination changes the bacterial diversity of soil from around Scott Base, Antarctica. FEMS Microbiol Ecol 2005; 53: 141-155.

118. Smith JJ, Tow LA, Stafford W, et al. Bacterial diversity of three different Antarctic cold desert mineral soils. Microb Ecol 2006; 51: 413-421.

119. Aislabie JM, Chhour K-L, Saul DJ, et al. Dominant bacteria in soil of Marble Point and Wright Valley, Victoria Land, Antarctica. Soil Biol Biochem 2006; 38: 3041-3056.

120. Buckley DH and Schmidt TM. Exploring the biodiversity of soil: A microbial rain forest. In: Staley JT, Reysenbach A-L, (Eds.), Biodiversity of Microbial Life, 2002; 183-208. New York: WileyLiss

121. Learn-Han L, Yoke-Kqueen C, Shiran M, et al. Identification of actinomycete communities in Antarctic soil from Barrientos Island using PCR-denaturing gradient gel electrophoresis. Gen Mol Res 2012; 11(1): 277-291.

122. Lee L-H, Cheah Y-K, Sidik SM, et al. Molecular characterization of Antarctic actinobacteria and screening for antimicrobial metabolite production. World J Microbiol Biotechnol 2012; 28(5): 2125-2137.

123. Lee L-H, Cheah Y-K, Syakima AMN et al. Analysis of Antarctic proteobacteria by PCR fingerprinting and screening for antimicrobia secondary metabolites. Gen Mol Res 2012; 11(2): 1627-1641

124. Zhang XJ, Yao TD, Ma XJ, et al. Analysis of the characteristics of microorganisms packed in the ice core of the Malan Glacier, Tibet, China. Sci China Ser D Earth Sci 2001; 44: 396-374.

125. Wawrik B, Kutliev D, Abdivasievna UA, et al. Biogeography of Actinomycete Communities and Type II Polyketide Synthase Genes in Soils Collected in New Jersey and Central Asia. Appl Environ Microbiol 2007; 73: 2982-2989.

126. Goshi K, Uchidam A, Lezhava A, et al. Cloning and analysis of the telomere and terminal inverted repeat of the linear chromosome of Streptomyces griseus. J Bacteriol 2002; 184: 3411-3415.

127. Lee L-H, Cheah Y-K, Sidik SM, et al. Barrientosiimonas humi gen. nov., sp. nov., An actinobacterium of the family Dermacoccaceae. Int J Syst Evol Microbiol 2013; 63(1): 241-248.

128. Rojas JL, Martín J, Tormo JR, et al. Bacterial diversity from benthic mats of Antarctic lakes as a source of new bioactive metabolites. Mar. Genomics 2009; 2: 33-41.

129. Wang GY, Graziani E, Waters B, et al. Novel natural products 
from soil DNA libraries in a streptomycete host. Org Lett 2000; 2 : 2401-2404

130. MacNeil IA, Tiong CL, Minor C, et al. Expression and isolation of antimicrobial small molecules from soil DNA libraries. J Mol Microbiol Biotechnol 2001; 3: 301-308.

131. Lefevre F, Robe P, Jarrin C, et al. Drugs from hidden bugs: Their discovery via untapped resources. Res Microbiol 2008; 159: 153-161.

132. Demain AL. Microbial natural products: Alive and well in 1998. Nat Biotechnol 1998; 16: 3-4.

133. Pompe S, Simon J, Wiedemann PM, et al. Future trends and challenges in pathogenomics. EMBO Rep 2005; 6: 600-605.

134. Lee L-H, Zainal N, Azman A-S, et al. Mumia flava gen. nov., sp. nov., an actinobacterium of the family Nocardioidaceae. Int J Syst Evol Microbiol, 2014; 64(5): 1461-1467.

135. Zainal N, Ser H-L, Yin W-F, et al. Streptomyces humi sp. nov., an actinobacterium isolated from soil of a mangrove forest. Antonie Van Leeuwenhoek 2016; 109(3): 467-474.

136. Lee L-H, Azman A-S, Zainal N, et al. Microbacterium mangrovi sp. nov., an amylolytic actinobacterium isolated from mangrove forest soil. Int J Syst Evol Microbiol 2014; 64(10): 3513-3519.

137. Azman A-S, Othman IS, Velu S, et al. Mangrove rare actinobacteria: Taxonomy, natural compound and discovery of bioactivity. Front Microbiol 2015; 6: 856.

138. Lee L-H, Azman A-S, Zainal N, et al. Sinomonas humi sp. nov., an amylolytic actinobacterium isolated from mangrove forest soil. Int J Syst Evol Microbiol 2015; 65(3): 996-1002.

139. Cheah YK, Lee LH, Radu S, et al. Isolation and rapid identification of streptomonospora, a strictly halophilic filamentous actinomycetes from antarctic soil (Barrientos Island, Antarctic). ASM Sci J 2009; $3(2)$

140. Ser H-L, Palanisamy UD, Yin W-F, et al. Presence of antioxidative agent, Pyrrolo [1, 2-a] pyrazine-1, 4-dione, hexahydro-in newly isolated Streptomyces mangrovisoli sp. nov. Front Microbiol 2015; 6 : 854.

141. Law JW-F, Ser H-L, Duangjai A, et al. Streptomyces colonosanans sp. nov., A novel actinobacterium isolated from Malaysia mangrove soil exhibiting antioxidative activity and cytotoxic potential against human colon cancer cell lines. Front Microbiol 2017; 8: 877.

142. Lee L-H, Zainal N, Azman A-S, et al. Streptomyces pluripotens sp. nov., A bacteriocin-producing streptomycete that inhibits meticillinresistant Staphylococcus aureus. Int J Syst Evol Microbiol 2014; 64(9): 3297-3306

143. Ser H-L, Law JW-F, Tan W-S, et al. Genome sequence of bioactive streptomycete isolated from mangrove forest in East Malaysia, Streptomyces monashensis MUSC $1 \mathrm{~J}^{\mathrm{T}}$. Prog Drug Discov Biomed Sci 2019; 2(1): a0000045.

144. Tan LT-H, Chan K-G, Khan, TM, et al. Streptomyces sp. MUM212 as a source of antioxidants with radical scavenging and metal chelating properties. Front Pharmacol 2017; 8: 276.

145. Azman A-S, Othman IS, Velu S, et al. Mangrove rare actinobacteria: Taxonomy, natural compound and discovery of bioactivity. Front Microbiol 2015; 6: 856.

146. Tan LT-H, Chan K-G, Pusparajah P, et al. Mangrove derived Streptomyces sp. MUM265 as a potential source of antioxidant and anticolon-cancer agents. BMC Microbiol 2019; 19(1): 38.

147. Zainal N, Ser H-L, Yin W-F, et al. Streptomyces humi sp. nov., An actinobacterium isolated from soil of a mangrove forest. Antonie Van Leeuwenhoek 2016; 109(3): 467-474.

148. Cheah YK, Lee L-H, Chieng CYC, et al. Isolation, identification and screening of Actinobacteria in volcanic soil of Deception Island (the Antarctic) for antimicrobial metabolites. Pol Polar Res 2015; 36(1)

149. Lee LH, Chan K-G, Stach J, et al. The search for biological active agent (s) from actinobacteria. Front Microbiol 2018; 9: 824

150. Lee LH, Ser HL, Ab Mutalib NS, et al. Winning the war against colon cancer chemo-preventive potential of novel streptomyces species derived from mangrove forst in Malaysia. Gut 2018; 67: A13-A14.

151. Lee LH, Law JWF, Khan TM, et al. Unveiling the anti-colon cancer potential of sarawak mangrove-derived novel streptomycetes. Gut 2019; 68: A42-A43.

152. Getha K and Vikineswary S. Antagonistic effects of Streptomyces violaceusniger strain G10 on Fusarium oxysporum f.sp. cubense race 4: Indirect evidence for the role of antibiosis in the antagonistic process. J Ind Microbiol Biotechnol 2002; 28: 303-310.

153. Vercesi A, Nasini $G$ and Locci R. Biological and chemical characterization of the antibiotic activity of Streptomyces species isolated from grapevine carposphere. Actinomycetes 1992; 3: 12-18.

154. Wery N, Gerike U, Sharman A, et al. Use of a packed-column bioreactor for isolation of diverse protease-producing bacteria from antarctic soil. Appl Environ Microbiol 2003; 69: 1457-1464.

155. Miteva VI, Sheridan PP and Brenchley JE. Phylogenetic and physiological diversity of microorganisms isolated from a deep Greenland glacier ice core. Appl Environ Microbiol 2004; 70: 202213.

156. Sponga F, Cavaletti L, Lazzarini A, et al. Biodiversity and potential of marine-derived microorganisms. J Biotechnol 1999; 70: 65-69.
157. Williams DH, Stone MJ, Hauck PR, et al. Why are secondary metabolites (natural products) biosynthesized? J Nat Prod 1989; 52: 1189-1208.

158. Peczyńska-Czoch W and Mordarski M. Actinomycete enzymes. In: Actinomycetes in Biotechnology. Goodfellow, M, Williams, ST, and Mordarski M. (eds.). 1988; 219-283. San Diego: Academic Press.

159. Ignatova $\mathrm{Z}$, Gousterova A, Spassov G, et al. Isolation and partial characterization of extracellular keratinase from a wool degrading thermophilic actinomycete strain Thermoactinomyces candidus. Can J Microbiol 1999; 45: 217-222.

160. Pettett LM and Kurtböke DI. Development of an environmentally friendly biofertilizer with keratin degrading and antibiotic producing actinomycetes. Actinomycetol 2004; 18: 34-42.

161. Crawford DL. Lignocellulose decomposition by selected Streptomyces strains. Appl Environ Microbiol 1978; 35: 1041-1045.

162. Ramachandra M, Crawford DL and Hertel G. Characterization of an extracellular lignin peroxidase of the lignocellulolytic actinomycete Streptomyces viridosporus. Appl Environ Microbiol 1988; 54: $3057-$ 3063.

163. Crawford DL, Pometto III AL and Crawford RL. Lignin degradation by Streptomyces viridosporus: Isolation and characterization of a new polymeric lignin degradation intermediate. Appl Environ Microbio 1983; 45: 898-904.

164. Pasti MB, Pometto III AL, Nuti MP, et al. Lignin-solubilizing ability of actinomycetes isolated from termite (Termitidae) gut. Appl Environ Microbiol 1990; 56: 2213-2218.

165. Okazaki K and Tagawa K. Purification and properties of chitinase from Streptomyces cinereoruber. J Ferment Bioeng 1991; 71: 237-241.

166. Gomes RC, Semêdo LTAS, Soares RMA, et al. Chitinolytic actinomycetes from a Brazilian tropical soil active against phytopathogenic fungi. World J Microbiol Biotechnol 2000; 16: 109-110.

167. Montiel MD, Rodríguez J, Pérez-Leblic MI, et al. Screening of mannanases in actinomycetes and their potential application in the biobleaching of pine kraft pulps. Appl Microbiol Biotechnol 1999; 52: 240-245

168. Berens S, Kaspari H and Klemme J-H. Purification and characterization of two different xylanases from the thermophilic actinomycete Microtetraspora flexuosa SIIX. Antonie Leeuwenhoek 1996; 69: 235241.

169. Somasundaram $\mathrm{P}$ and Ahmed A. Production, purification and characterization of xylanase from an actinomycetes strain B23 (Streptomyces noboritoensis). Malays J Sci 1996; 17: 95-101.

170. Kim B, Al-Tai AM, Kim SB, et al. Streptomyces thermocoprophilus sp. nov., a cellulase-free endo-xylanase-producing streptomycete. Int J Syst Evol Microbiol 2000; 50: 505-509.

171. Busch JE and Stutzenberger FJ. Amylolytic activity of Thermomonospora fusca. World J Microbiol Biotechnol 1997; 13: 637-642.

172. Pasti MB and Belli ML. Cellulolytic activity of actinomycetes isolated from termites (Termitidae) gut. FEMS Microbiol Lett 1985; 26: 107-112.

173. Waldron Jr CR, Becker-Vallone CA and Eveleigh DE. Isolation and characterization of a cellulolytic actinomycete Microbispora bispora. Appl Microbiol Biotechnol 1986; 24: 477-486.

174. Goodfellow M and Williams ST. Ecology of actinomycetes. Ann Rev Microbiol 1983; 37: 189-216.

175. Arai T. What are actinomycetes? In: Atlas of Actinomycetes. Miyadoh S, Hamada M, Hotta K, et al. (eds.). 1997; 176-177. Japan: Asakura Publishing Co. Ltd.

176. Goodfellow M and O'Donnell AG. Search and discovery of industrially significant actinomycetes. In Microbial Products: New Approaches, 1989; 343-383. Edited by Baumberg S, Hunter I and Rhodes M. Cambridge: Cambridge University Press.

177. Osburne MS, Grossman TH, August PR, et al. Tapping into microbial diversity for natural products drug discovery. ASM News 2000; 7: 411417.

178. Torsvik V and Øvreås L. Microbial diversity and function in soil: From genes to ecosystems. Curr Opin Microbiol 2002; 5: 240-245.

179. Ong KS, Aw YK, Lee LH, et al. Burkholderia paludis sp. nov., An antibiotic-siderophore producing novel Burkholderia cepacia complex species, isolated from Malaysian tropical peat swamp soil. Front Microbiol, 2016; 7: 2046

180. Aw Y-K, Ong K-S, Lee L-H, et al. Newly isolated Paenibacillus tyrfis sp. nov., from Malaysian tropical peat swamp soil with broad spectrum antimicrobial activity. Front Microbiol, 2016; 7: 219.

181. Ong KS, Letchumanan V, Law JW-F, Yule, et al. Microbes from peat swap forest - The hidden reservoir for secondary metabolites. Prog Microbes Mol Biol 2020; 3(1): a0000077.

182. Bernan VS, Greenstein M and Carter GT. Mining marine microorganisms as a source of new antimicrobials and antifungals. Curr Med Chem 2004 3: $181-195$.

183. Cohen ML. Changing patterns of infectious disease. Nature 2000; 406 ; 762-767

184. Taylor LH, Latham SM and Woodhouse MEJ. Risk factors from human disease emergence. Philos T Roy Soc B 2001; 356: 983-989.

185. Law JW-F, Letchumanan V, Tan LT-H, et al. The Rising of "Modern Actinobacteria" Era. Prog Microbes Mol Biol 2020; 3(1): a0000064. 